\title{
The impact of resilience and perceived organisational support on employee engagement in a competitive sales environment
}

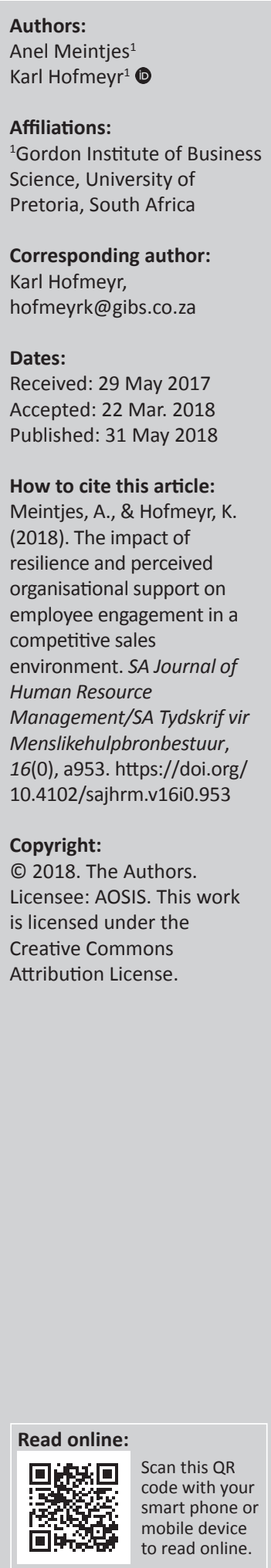

Orientation: Understanding the impact of resilience and perceived organisational support on employee engagement in a competitive sales environment.

Research purpose: The aim of this study was to explore the relationship between resilience, perceived organisational support and employee engagement among pharmaceutical sales employees in a competitive sales environment; and to establish whether resilience and perceived organisational support hold predictive value for employee engagement.

Motivation for the study: Limited research has focused on the unique context of employee engagement as a construct in professional sales. A broader understanding of resilience and perceived organisational support can provide sales organisations with a lever to create an environment where sales employees are more fully engaged.

Research design, approach and method: A quantitative, exploratory, cross-sectional survey approach was used. A sample of 125 sales representatives from a South African pharmaceutical organisation participated in the research. The measuring instruments included the Utrecht Work Engagement Scale (UWES), Brief Resilience Scale (BRS) and the Perceived Organisational Support Scale (POS).

Main findings: Perceived organisational support, but not resilience impacted employee engagement in a competitive sales environment.

Practical and managerial implications: Sales organisations' interventions to improve sales employee engagement should focus on perceived organisational support.

Contribution: The individual role of each construct provided insight into the sales context. The relationship between the constructs offered a different lens through which the drivers of employee engagement in sales can be viewed. This study contributes towards sales literature by including positive psychology and organisational support in a model of employee engagement.

\section{Introduction}

\section{Key focus of the study}

Understanding the impact of resilience and perceived organisational support (POS) on employee engagement in a competitive sales environment.

\section{Background}

Sales employees are often the most important channel through which companies execute their strategies and generate revenue (Morelli \& Braganza, 2012). Selling involves constant strain that includes competing with competitors, meeting sales targets and dealing with rejection (Loveland, Lounsbury, Parks, \& Jackson, 2015). The topography of the current sales landscape is dynamic, evolving and uncertain. Sales tasks are often conducted in a competitive environment with sales positions often resulting in emotional exhaustion (Rajan \& Srinivasan, 2015). Emotional exhaustion is often viewed as the opposite of engagement, or similar to being disengaged (Bande, FernándezFerrín, Varela, \& Jaramillo, 2015).

Contemporary organisations need employees who feel energetic and engaged with their work (Albrecht, Bakker, Gruman, Macy, \& Saks, 2015). The significance of employee engagement within an organisation relates to both the organisation and the employee. The benefits to 
organisations include increased financial turnover (Rothmann \& Rothmann, 2010), revenue growth (Werhane \& Royal, 2009), gross profit (Towers Watson, 2015), operating profit (Towers Watson, 2012), greater customer satisfaction and increased productivity (Saks \& Gruman, 2014). Benefits to the employee include self-reported indicators of greater health and well-being (Saks \& Gruman, 2014), job satisfaction and lower staff turnover (Rothmann \& Rothmann, 2010). Despite extensive research into employee engagement, relatively low levels of engagement continue to be reported by organisations across the globe (Albrecht et al., 2015). Investigating the drivers of engagement is therefore vital to understand how to enhance employee engagement in the work environment.

Employee engagement is a positive organisational outcome which has been associated with resilience (King, Newmans, \& Luthans, 2015; Mache et al., 2014; Shin, Taylor, \& Seo, 2012). The growing performance expectations of the current business environment cannot be met with average performance. Organisations thus require employees who are resilient and can succeed in chaos and grow in the face of difficulty, uncertainty and constant change (Kotzé \& Nel, 2013). In sales, resilience enables the salesperson to sustain a constructive response in the face of adversity by focusing on the positive side of adversity, while simultaneously inhibiting negative responses (Krush, Agnihotri, Trainor, \& Krishnakumar, 2013). People with a low level of resilience are more emotionally unstable when faced with difficulty (Bande et al., 2015; Bonanno, Papa, \& O'Neill, 2001), less flexible to change and more resistant to new experiences (Bande et al., 2015).

Under the influence of a dynamic business environment, it is natural for employees to develop expectations regarding the extent to which the organisation cares about their wellbeing and appreciates their contribution in achieving business goals. A sense of being valued and appreciated is a key driver of positive organisational outcomes such as engagement. Feeling valued is not only highly organisation specific but also specific for different employee groups within an organisation (Gupta \& Sharma, 2016). The aim of this research was to explore resilience of the individual and perceived support of the organisation as potential drivers of employee engagement in a competitive sales environment.

\section{Trends from the research}

Although employee engagement has been identified as a significant driver of revenue and financial performance in modern organisations (Bakker \& Demerouti, 2014; Verbeke, Dietz \& Verwaal, 2011), limited research has focused on the unique context of employee engagement as a construct in professional sales (Medhurst \& Albrecht, 2016). Existing sales literature on employee engagement focuses mainly on drivers such as role conflict, role ambiguity, adaptive selling behaviour (Miao \& Evans, 2013), trust, psychological contract and interactional justice (Agarwal, 2014).
Various studies indicate that there is a relationship between resilience and engagement (Bakker, Albrecht, \& Leiter, 2011; Bande et al., 2015; King et al., 2015; Mache et al., 2014; Shin et al., 2012). Resilience appears to be closely linked to vigour, one of the three dimensions of employee engagement (Schaufeli, Salanova, González-Romá, \& Bakker 2002). Medhurst and Albrecht (2011) conclude similarly that resilience positively influences sales performance through vigour and also the investment of high levels of energy when faced with challenging situations. Bande et al. (2015) argue that resilience can lead to a subjective assessment of well-being that includes engagement. In the South African context, Simons and Buitendach (2013) observe a practical and statistically significant relationship between total employment engagement scores and resilience among call centre employees. The call centre environment is comparable to a competitive sales environment with respect to the negative effect of emotional exhaustion on employee wellbeing (Johnson et al., 2005). There appears to be no published studies in South Africa investigating the relationship between employee engagement and resilience in a sales environment.

Perceived organisational support as a construct is positively associated with employee engagement (Kurtessis et al., 2015; Mathumbu \& Dodd, 2013). Research by Rothmann and Rothmann (2010) indicates that organisational support is a strong predictor of employee engagement in various South African industries. In the context of sales, this association is underpinned by the stressful nature of sales positions accompanied by emotional exhaustion, which ultimately has important implications for levels of engagement and the need for organisational support (Kurtessis et al., 2015). Salespeople with a subdued perception may also experience diminished job involvement and identification with the organisation, which can lead to less dedication and absorption (DeConinck, DeConinck, \& Lockwood, 2015).

\section{Research objectives}

The premise of this research is that employee engagement is a desirable organisational outcome in a competitive sales environment. Although there is limited empirical evidence concerning which factors predict employee engagement in a sales environment, this research aims to explore resilience and perceived organisational support (POS) as possible predictors.

The first objective of the study was to explore the relationship between resilience and employee engagement. Despite the importance of resilience in a sales environment, limited research has focused on resilience in salespeople (Loveland et al., 2015). Resilience appears to be closely linked to vigour, one of the three dimensions of employee engagement (Medhurst \& Albrecht, 2011; Schaufeli et al., 2002). Engagement was defined as an aroused psychological state of energy and focus aimed at addressing the situational and task-related demands in a sales environment (Medhurst \& Albrecht, 2016). According to the authors, salesperson engagement shares similar characteristics to the existing 
conceptualisation of engagement in terms of vigour, dedication and absorption (Schaufeli et al., 2002).

The second objective of the study was to explore the relationship between POS and employee engagement. Although many studies have focused on POS as a construct, few studies have focused on POS in a sales environment (DeConinck et al., 2015). The stressful nature of sales positions accompanied by emotional exhaustion may have important implications for the incumbents' level of engagement and need for organisational support. Emotional exhaustion appears to be highly correlated with POS (Kurtessis et al., 2015). This correlation has important practical implications in a stressful work environment where employees are subjected to emotional exhaustion. This importance is accentuated in a sales environment where the sales force work alone in different geographical locations and are detached from the organisation (Morelli \& Braganza, 2012).

\section{The potential value-add of the study}

The purpose of this study was to contribute to the theoretical understanding of resilience and POS as potential drivers of employee engagement in a competitive sales environment. Resilience as a personal resource is pliable and open to development (Krush et al., 2013). An improved understanding of resilience can make a contribution to human resource management practices in terms of training and employee development. Studying resilience as a potential driver of employee engagement will make a contribution towards the academic field of positive psychology and positive organisational behaviour. Exploring salespeople's perceptions of organisational support offers valuable insights into the employee-organisation relationship in terms of concepts such as feeling valued as an employee (Gupta \& Sharma, 2016), levels of supervisor support (DeConinck et al. 2015), fairness (Morelli \& Braganza, 2012) and human resource management practices related to training, performance appraisal and compensation systems (Zampetakis, 2014). These insights can be utilised to create a more supportive environment with improved employee engagement and the ability to cope in a stressful profession (DeConinck et al. 2015). Studying the relationship between employee engagement and POS will make a contribution to the academic fields of positive organisational behaviour and organisational support theory.

In the next section, a synthesis and critical evaluation of the literature dealing with the constructs will be provided, followed by an explanation of the research design, reporting of results and a detailed discussion of the results.

\section{Ethical consideration}

Ethical clearance was obtained from the University of Pretoria's Gordon Institute of Business Science Research Ethics Committee. All respondents were assured of confidentiality and anonymity, with participation being voluntary.

\section{Literature review Employee engagement}

The emergence of engagement research in the 21st century is related to the developing importance of human capital, involvement of employees in organisations (Bailey, Madden, Alfes, \& Fletcher, 2015; Schaufeli, 2013) and the need for businesses to maximise the inputs of employees (Rothmann \& Rothmann, 2010). The first theoretical foundation of engagement stems from the work of Kahn (1990, p. 694), who views personal role engagement as the individual's emotional, cognitive and physical expression of their authentic self at work. To be fully engaged, individuals must display their full selves within their work role (Bailey et al., 2015). Building on the work of Kahn (1990, p. 694), Rich, Levine and Crawford (2010) state that individuals who are engaged invest their head, heart and hands in their performance. The second theoretical view of engagement is an activated positive state of mind directed towards work tasks. This view is founded on the concept of engagement and burnout being opposites of each other. This theoretical view defines engagement as 'a positive, fulfilling, work-related state of mind that is characterised by vigour, dedication and absorption towards work activities' (Schaufeli et al., 2002, p. 71). Vigour assists individuals to foster a more proactive work style (Coetzee, Schreuder, \& Tladinyane, 2014) and is characterised by high levels of energy and mental resilience. In addition, vigour is associated with persistent, conscientious efforts to devote oneself to work and when facing difficulties (Coetzee et al., 2014). Dedication involves being strongly involved in one's work with a sense of pride and enthusiasm. Absorption involves being completely concentrated on and happily engrossed in one's work, whereby time passes quickly and it is difficult to detach from work (Bailey et al., 2015; Schaufeli, 2013).

Employee engagement has been identified as a significant driver of salesperson performance in modern sales organisations (Albrecht \& Medhurst, 2011; Rapp, Bachrach, Panagopoulos, \& Ogilvie, 2014). According to Albrecht et al. (2015), the direct influence of employee engagement on sales performance assists organisations to achieve a competitive advantage through improved customer satisfaction, increased selling intentions and a more favourable attitude towards products and resources. The impact of employee engagement in sales is also related to sales force turnover. Sales positions are subject to high turnover rates and are often challenging positions to fill (Bande et al., 2015). A high level of employee engagement is associated with 37\% lower absenteeism (Harter, Schmidt, Agrawal, \& Plowman, 2013) and has the ability to reduce the negative impact of sales force turnover on the business results of sales organisations (Bande et al., 2015).

A study by Medhurst and Albrecht (2016) interprets engagement among salespeople as an aroused psychological state of focus and energy, aimed at addressing the situational and task-related opportunities and demands encountered in 
sales positions. According to these authors, salesperson engagement shares similar characteristics with the existing conceptualisation of engagement in terms of vigour, dedication and absorption (Schaufeli et al., 2002).

\section{Resilience}

Bardoel, Pettit, De Cieri and McMillan (2014) propose that one of the theoretical approaches to resilience applied in the workplace is based on positive psychology and positive organisational behaviour. In positive psychology, resilience is described as a response where an individual adapts positively to exposure to a subjectively significant threat, risk or difficulty, without losing the ability to function normally (Bardoel et al., 2014; Bonanno, 2004). Recent applications of resilience in occupational literature focus on occupations associated with a high risk for experiencing acute stress and trauma, such as police officers and fire fighters (Freedman, 2004; Peres et al., 2011; Vanhove, Herian, Peres, Harms \& Lester, 2015). However, Vanhove et al. (2015) propose that resilience may also be of significance in an employment context where stress can accumulate over time because of influences such as work overload, work relationships, lack of resources and support, emotional and physical exhaustion and work-life conflict. Johnson et al. (2005) identify teachers, ambulance workers, customer and social service workers, call centre staff and prison officers as examples of jobs where the abovementioned influences and accumulated stress can have a negative effect on employee well-being and organisational functioning (Vanhove et al., 2015). Although no reference is made to sales employees, the nature of sales positions suggests that the sales environment can also be viewed as an employment context where resilience is of significance. Krush et al. (2013) support this view with the observation that resilience enables positive responses towards adversity, while simultaneously inhibiting negative responses.

Resilience in the workplace is also defined as the 'positive psychological capacity to "bounce back" from adversity, uncertainty, conflict, failure, or even positive change, progress and increased responsibility' (Kotzé \& Nel, 2013; Luthans, 2002). According to the literature, a key component of resilience is whether an individual demonstrates simultaneous growth and positive change following a stressful event. Although some definitions refer to positive change, most simply require successful adaptation to adversity (Bande et al., 2015). In competitive sales, adaptation unaccompanied by growth or positive change will not enable a sales force to successfully meet sales targets or deal with rejection and competitors.

Employee engagement is a positive organisational outcome associated with resilience (King et al., 2015; Mache et al., 2014; Shin et al., 2012). Bande et al. (2015) report that resilience can lead to a subjective assessment of well-being that includes engagement. However, this prediction includes all the dimensions of self-efficacy, optimism, hope and resilience. This raises questions as to whether this position can be proposed by taking into account only the dimension of resilience. Luthans, Vogelgesang and Lester (2006) provide a possible explanation by arguing that resilient people may take a more pragmatic approach to dealing with stress than those with a high level of optimism or hope. Medhurst and Albrecht (2011) propose that resilience positively influences sales performance through vigour and the investment of high levels of energy when faced with challenging situations. Vigour as a dimension of employee engagement could therefore be positioned as a driver of employee engagement among sales employees (Schaufeli, 2013). This research study formulated the following hypothesis:

- Hypothesis 1: Can it be predicted with reasonable accuracy that a relationship exists between resilience and employee engagement in a sales environment?

\section{Perceived organisational support}

Organisational support theory has attracted considerable attention because of its potential ability to explain the employee-employer relationship. Various studies indicate that POS is related to behavioural outcomes for both employees and organisations (Caesens, Marique, Hanin, \& Stinglhamber, 2016). Beneficial organisational behavioural outcomes include organisational commitment (Baran, Shanock, \& Miller, 2012; Connelly, Gallagher, \& Gilley, 2007), organisational citizenship behaviour (Baran et al., 2012; Coyle-Shapiro \& Morrow, 2006), performance (Webster \& Adams, 2010) and job satisfaction (Kurtessis et al., 2015). Beneficial employee behavioural outcomes related to POS include increased trust in the organisation, job satisfaction, positive psychological well-being and increased in-role performance. Unfavourable behavioural outcomes include job stress, burnout and withdrawal behaviour. Under the umbrella of organisational support theory, fairness, human resource practices and supervisor support are important antecedents of POS (Baran et al., 2012; Kurtessis et al., 2015).

Perceived organisational support as a construct is positively associated with employee engagement (Kurtessis et al., 2015; Mathumbu \& Dodd, 2013). According to organisational support theory, employees also develop beliefs regarding the extent to which the organisation cares about their well-being and appreciates their contribution to achieving business goals. Feeling appreciated is a key driver of positive organisational outcomes such as engagement (Gupta \& Sharma, 2016).

The perception of organisational support can be viewed from an organisational or employee perspective. Tavares, van Knippenberg and van Dick (2015) argue that the perception of organisational support can be viewed by the organisation as a social currency offered with the aim of increasing the quality of the employer-employee relationship. This relationship is discretionary in nature, which means that employees can determine the extent to which they engage in extra-role efforts to benefit the organisation and its employees. 
From the viewpoint of the employee, this relationship is reciprocal in nature as the employee feels obligated to support their employer with the expectation that increased performance will be noticed and rewarded. According to social exchange theory, employees with high POS will engage in greater job-related efforts (Kurtessis et al., 2015).

In a competitive and results-orientated milieu, sales representatives are more likely to succeed when they feel supported rather than directed (Adamson, Dixon, \& Tolman, 2013). Sales representatives often work alone in different geographical locations and are detached from the organisation (Morelli \& Braganza, 2012). Working outside the boundaries of the organisation in a complex sales environment may accentuate the need for organisational support. DeConinck et al. (2015) are of the opinion that with a subdued perception of organisational support, salespeople may also experience diminished job involvement and identification with the organisation, which can ultimately lead to less dedication and absorption. Dedication and absorption are critical dimensions of employee engagement based on the theoretical foundation of engagement as a positive, work-related state of mind (Schaufeli \& Bakker, 2004). Based on the aforementioned, the following hypothesis is presented:

Hypothesis 2: Can it be predicted with reasonable accuracy that a relationship exists between perceived organisational support and employee engagement in a sales environment?

Given these research findings, the researchers proposed a positive relationship between resilience and POS and employee engagement, respectively.

\section{Measurement of constructs}

Most existing empirical research on employee engagement makes use of either the Utrecht Work Engagement Scale (UWES) (Gupta \& Sharma, 2016; Schaufeli \& Bakker, 2003) or the Job Engagement Scale (JES) (Gupta \& Sharma, 2016; Rich \& Levine, 2010). The JES is grounded in theories of selfexpression at work and based on Kahn's (1990, p. 694) definition of engagement which includes physical, cognitive and affective dimensions (Gupta \& Sharma, 2016). The UWES is grounded in burnout literature (Gupta \& Sharma, 2016; Maslach \& Leiter, 1997) and defines engagement as a positive, work-related state of mind with a strong sense of vigour towards, dedication to and absorption in work activities. According to Saks and Gruman (2014), the dimensions of the UWES are inconsistent with Kahn's (1990) original assertion that engagement is an indication of bringing one's true self to the performance of one's role (Saks \& Gruman, 2014). The authors argue that bringing one's true self to the performance of one's role involves a much deeper and more authentic level of engagement than just devoting energy and dedication to the performance of work activities. However, a systematic review involving 214 studies found the UWES to be the most widely adopted measure of engagement (Schaufeli \& Bakker, 2003).
The challenges of developing an operational definition for resilience have led to different approaches to measuring the construct (Windle et al., 2011). There is currently no gold standard in terms of measuring resilience. Most existing measures have concentrated on examining resources or protective factors that might facilitate a resilient outcome. In contrast, the Brief Resilience Scale (BRS) is designed to measure resilience as an outcome measure defined as the ability to recover from stress. The BRS is the only measure that assesses resilience based on its original and most basic meaning as relating to the ability to bounce back from stress (Smith, Tooley, Christopher, \& Kay, 2010). In the South African context, the BRS was used in a small mixed method study by Edwards, Edwards and Highley (2015), with no references made to internal consistency scales using Cronbach's alpha. Additional measurement scales used in the local context include the Resilience Scale (Koen, van Eeden, \& Wissing, 2011) and the Adult Resilience Indicator (Kotzé \& Nel, 2013). A criticism from Jowkar, Friborg and Hjemdal (2010) is that most resilience measurement scales ignore the family and social aspects of resilience. An additional concern is that most of the resilience measurement instruments have been developed and utilised in the Western world, with concerns regarding their validity in non-western population (Abiola \& Udofia, 2011; Dageid \& Gronlie, 2015). Recent empirical research has demonstrated the BRS's reliability and validity in emerging countries such as Malaysia (Amat et al, 2014) and China (Lai \& Yue, 2014).

The original 36-item POS Scale developed by Eisenberger (1986) has gained considerable interest because of the benefit of understanding the employee-employer relationship. The scale measures employees' perceptions regarding the extent to which employers value the contribution of employees and care about their well-being. Shorter versions of the scale are now available. Correlations among factor scores of POS Scale scores suggest that both the 8 -item and 16 -item version are just as effective as the original 36-item version, but are more efficient (Worley, Fuqua, \& Hellman, 2009). A 6-item version of the POS Scale was used in a multi-industry, multigenerational and multicultural study with a high level of reliability (Smit, Stanz, \& Bussin, 2015). In the South African context, the 8-item POS Scale has been used in a study of nurses and had acceptable levels of reliability and validity (Mathumbu \& Dodd, 2013).

\section{Research design Research approach}

Quantitative research methods were used to test the predetermined hypotheses regarding the relationship between the variables of resilience, organisational support and employee engagement within a cross-sectional time frame. Factor analysis, multiple regression and analysis of variance tests were applied to determine whether a predictive relationship of significance exists among the variables. Factor validity and reliability were determined for all measurement scales. 


\section{Research method Research participants}

The study made use of a convenience sampling approach. A survey was conducted on sales representatives from a Johannesburg Stock Exchange listed pharmaceutical company $(N=220)$ in South Africa. A response rate of $56.8 \%$ yielded a sample of 125 participants. The Monte Carlo simulation was used to determine the minimum sample size needed for multiple regression or prediction (Knofczynski \& Mundfrom, 2007). From this method, it was inferred that for the purpose of this study, the minimum sample size needed for two predictor variables was 90 cases. The demographic characteristics of the sample indicate that almost $70 \%$ of the sales force were younger than or equal to 40 years of age, while $25 \%$ of the sales force had been employed by the organisation for 1 year or less. Female participants accounted for $69 \%$ of the sample, the majority of the respondents were white people $(45 \%)$, followed by Indians (24\%) and black people $(17 \%)$, with the minority from the mixed race population (14\%).

\section{Measuring instruments}

The UWES, a 9-item questionnaire, measured employee engagement on a 7-point Likert scale ranging from $1=$ never to $7=$ always. Employee engagement was defined as a positive, fulfilling work-related state of mind that is characterised by the dimensions of vigour, dedication and absorption (Schaufeli, Bakker, \& Salanova, 2006). An example of a question in this scale is: 'At my work, I feel bursting with energy'.

The 6-item BRS measured resilience as a single construct and the first independent variable (Smith et al., 2008). The BRS was chosen based on its ability to measure resilience in its most basic form (to bounce back from stress, difficulty or setbacks). The BRS was scored on a 5-point Likert scale varying from $1=$ strongly disagree to $5=$ strongly agree. An example of a question in this scale is 'It is hard for me to snap back when something bad happens'.

The 8-item version of the POS Scale (Eisenberger, 1986) was used to measure POS, and the extent to which employers value the contribution of employees and care about their well-being. The POS Scale was scored by finding the mean of the eight items on a 7-point Likert scale, varying from $1=$ strongly disagree to $7=$ strongly agree. An example of a question in this scale is 'The organisation strongly considers my goals and values'.

\section{Research procedure}

A letter explaining the objective of the study and requesting participation in the survey was emailed to sales employees within the organisation. The measuring instruments were pretested with selected sales representatives from a division not participating in the study prior to being distributed to the entire sample, with no changes made after the testing phase.
Surveys were distributed to sales employees in paper-based form and via a link to an electronic format in Typeform ${ }^{\mathrm{TM}}$. Convenience sampling was used to select participants nationally from a sample frame consisting of 220 employees from which 125 responses were obtained for final analysis. The first section of the survey collected demographic information, whereas the second section consisted of a questionnaire combining the three measuring instruments.

\section{Statistical analysis}

Coded data were analysed with the IBM SPSS (Version 22) statistical software tool. Descriptive statistics were calculated to describe the mean, median, standard deviation, skewness and kurtosis of the various constructs. Factor analysis was used to determine the construct validity of all measurement scales (Zikmund, Babin, Carr, \& Griffin, 2010). First, the Kaiser-Meyer-Olkin (KMO) index and Bartlett's test of sphericity were inspected to determine whether factor analysis was a feasible option. Principle component analysis and a varimax rotation strategy were used to explore the factor structure of the various scales used within this study (Yong \& Pearce, 2013). Cronbach's alpha was employed to determine reliability and internal consistency with a coefficient alpha between 0.70 and 0.80 considered to be reflective of good reliability (Zikmund et al., 2010). The corrected item-total correlation was used as an additional measure of reliability by correlating the individual item score to the sum of all scores. A correlation coefficient greater than 0.3 indicated adequate item-total correlation (Field, 2013).

Multiple regression determined whether resilience and POS hold predictive value for employee engagement. All required assumptions for multiple regression analyses were met before the analyses were conducted. The predictive power and relative contribution of the independent variables were tested with hierarchical multiple regression by entering the variables in a predetermined order. Demographic variables were controlled for and forced into the first step to determine whether the independent variables were still able to explain the remaining variance of the dependent variable.

\section{Results}

\section{Validity and reliability of measurement scales}

All the scales were subjected to a factor and reliability analysis. Single factor structures were obtained for all scales, whereas acceptable reliabilities were obtained for all subscales and overall scales. The KMO index measure for sampling adequacy for employee engagement, resilience and POS exceeded the minimum accepted level of 0.6 for a good factor analysis (Pallant, 2005).

For the UWES, high factor loadings were observed in all nine items, and therefore, all items were included in the scale. A one-factor solution also seemed to best fit the data. All correlation coefficients were greater than 0.30 , indicating adequate item-total correlation. With an alpha of 0.93 , the UWES Scale was considered to be reliable with a high degree 
of consistency between multiple measurements of the scale. This level of reliability is within close range of a South African nurses study reporting an alpha coefficient of 0.79 (Mathumbu \& Dodd, 2013) and a comparable South African study of call centre employees that reported an alpha of 0.95 (Simons \& Buitendach, 2013).

For the BRS, the loadings of each of the items on the one component with factor loadings ranged from 0.43 to 0.81 exceeding the acceptable factor loading of 0.40 . Therefore, all six scale items were included in the scale. All correlation coefficients were greater than 0.30 , indicating adequate itemtotal correlation. The initial Cronbach's alpha for the BRS was 0.73. Item R5 ('I usually come through difficulty times with little trouble') lowered the scale's reliability and validity with a low correlation coefficient $(<0.30)$ and factor loading (0.434), and was subsequently removed from further analysis. There are no comparable South African studies reporting mean resilience scores based on the BRS.

For the POS Scale, high factor loadings were observed; therefore, all eight items were included in the scale. A onefactor solution also seemed to best fit the data. All correlation coefficients were greater than 0.30 , indicating adequate item-total correlation. With a Cronbach's alpha of 0.90, the POS Scale was considered to be reliable with a high degree of consistency between multiple measurements of the scale. These results are consistent with previous South African research indicating an acceptable level of reliability and validity for this scale with Cronbach's alpha values ranging from 0.71 (Mathumbu \& Dodd, 2013) to 0.89 (Smit et al., 2015).

\section{Descriptive statistics}

The descriptive statistics for all constructs are presented in Table 1. For employee engagement, a mean score of 5.77 indicated a high level of employee engagement. On the 7-point Likert scale, this indicated a high level of engagement experienced often (a few times a week). A standard deviation dispersion of 0.87 showed that the individual responses did not deviate much from the main score; the responses were therefore not polarised. Resilience had a mean score of 3.70 on a 5-point Likert scale presenting a high perceived level of resilience close to 'agree'. A standard deviation dispersion of 0.63 indicated that the individual responses deviated slightly from the main score. For POS, a mean score of 4.87 indicated a response close to 'slightly agree'. A standard deviation dispersion of 1.31 indicated that there was a large amount of variation in the individual responses.

In conclusion, descriptive statistics indicated a high perceived level of resilience and employee engagement, and a 'slightly agree' perception of POS.

\section{Multiple regression}

In Table 2, demographic variables (gender, age, length of service) predicted approximately $4 \%$ of the variance in employee engagement. Resilience predicted just more than $5 \%$ of the variance in employee engagement. Neither the demographic variables $(F=1.63, p>0.05)$ nor resilience $(F=1.50, p>0.05)$ was statistically significant predictor of employee engagement. Perceived organisational support predicted approximately 23\% of the variance in employee engagement $(F=27.20, p<0.05)$. In Table 3 , the regression coefficient of POS was statistically significant $(\beta=0.44, p<0.05)$.

TABLE 1: Descriptive statistics of constructs.

\begin{tabular}{lcc}
\hline Variable & Mean & SD \\
\hline Employee engagement & 5.77 & 0.87 \\
Resilience & 3.7 & 0.63 \\
Perceived organisational support & 4.87 & 1.31 \\
\hline
\end{tabular}

SD, standard deviation.

TABLE 2: Model summary of employee engagement.

\begin{tabular}{lccccc}
\hline Model & $\boldsymbol{F}$ Change & $\boldsymbol{R}$ & $\boldsymbol{R}^{\mathbf{2}}$ & $\begin{array}{c}\text { Adjusted } \boldsymbol{R} \\
\text { Square }\end{array}$ & Cohen's $\boldsymbol{f}^{\mathbf{2}}$ \\
\hline 1 & 1.632 & $0.197^{\mathrm{a}}$ & 0.039 & 0.015 & 0.04 \\
2 & 1.502 & $0.225^{\mathrm{b}}$ & 0.051 & 0.019 & 0.05 \\
3 & 27.200 & $0.477^{\mathrm{c}}$ & 0.227 & 0.195 & 0.29 \\
\hline
\end{tabular}

a, Predictors - (Constant), tenure, gender, age; ${ }^{b}$, Predictors - (Constant), tenure, gender, age TotalR; ' , Predictors - (Constant), tenure, gender, age, TotalR, TotalPOS.

\begin{tabular}{|c|c|c|c|c|c|}
\hline \multirow[t]{2}{*}{ Model } & \multirow[t]{2}{*}{ Variable } & \multicolumn{2}{|c|}{$\beta$} & \multirow[t]{2}{*}{$t$} & \multirow[t]{2}{*}{ Sig. } \\
\hline & & Standardised coefficients & Unstandardised coefficients & & \\
\hline \multirow[t]{4}{*}{1} & (Constant) & 6.258 & - & 18.213 & 0.000 \\
\hline & Gender & -0.315 & -0.169 & -1.865 & 0.065 \\
\hline & Age & 0.076 & 0.093 & 0.781 & 0.437 \\
\hline & Length of service & -0.019 & -0.177 & -1.467 & 0.145 \\
\hline \multirow[t]{5}{*}{2} & (Constant) & 5.696 & - & 9.953 & 0.000 \\
\hline & Gender & -0.31 & -0.166 & -1.837 & 0.069 \\
\hline & Age & 0.071 & 0.087 & 0.734 & 0.464 \\
\hline & Length of service & -0.018 & -0.165 & -1.367 & 0.174 \\
\hline & TotalR & 0.150 & 0.109 & 1.226 & 0.223 \\
\hline \multirow[t]{5}{*}{3} & (Constant) & 4.000 & - & 6.535 & 0.000 \\
\hline & Gender & -0.129 & -0.069 & -0.821 & 0.413 \\
\hline & Age & 0.084 & 0.102 & 0.951 & 0.344 \\
\hline & TotalR & 0.114 & 0.083 & 1.031 & 0.305 \\
\hline & TotalPOS & 0.293 & 0.442 & 5.215 & 0.000 \\
\hline
\end{tabular}

Sig., significance. 
Statistical power was increased with a large sample size $(N=125)$ than the required sample size of 90 . The sample size was sufficient with a medium effect size $(\beta \geq 0.2)$ and power of $80 \%$. The increase in power decreased the probability of a Type II error (false negative). With a critical $\alpha \leq 0.05$, there was only a $5 \%$ chance of a Type I error, or incorrectly rejecting the null hypothesis.

In conclusion, there is a statistically significant relationship between POS and employee engagement, but no statistically significant relationship between resilience and employee engagement.

\section{Discussion}

The main objective of the study was to determine whether resilience and POS are significant predictors of employee engagement. A discussion on the various constructs will be followed by the regression analysis.

\section{Hypothesis 1: Can it be predicted with reasonable accuracy that a relationship exists between resilience and employee engagement in a sales environment?}

Although resilience explained almost $5 \%$ of the variance in employee engagement, no statistically significant relationship was found with employee engagement. The results of this analysis contradict prior academic research indicating that employee engagement is a positive organisational outcome associated with resilience (King et al., 2015; Mache et al., 2014; Shin et al., 2012). In the South African context, Simons and Buitendach (2013) observed a practical and statistically significant relationship between total employee engagement scores and resilience among call centre employees. The call centre environment is similar to the sales environment in terms of emotional exhaustion and burnout.

Findings from Bakker et al. (2011) also suggest that resilience is an important predictor of work engagement. However, this prediction included additional dimensions of self-efficacy, optimism, hope and resilience. It is likely that the predictive power of resilience for engagement could be stronger if it was defined and quantified in conjunction with all the dimensions of psychological capital.

It is plausible that the relationship between resilience and employee engagement is more complex than what can be explained by a simple prediction model. Resilience may be a moderating variable between an independent variable and the outcome variable employee engagement. For example, the possibility of the moderating effects of resilience as a personal resource in the relationship between job resources and work engagement has been recognised in existing empirical research (Mäkikangas, Feldt, Kinnunen, \& Mauno, 2013; Xanthopoulou, Bakker, Demerouti \& Schaufeli, 2007). It is also possible that resilience as a personal resource may act as a mediating variable between an independent variable and the outcome variable of employee engagement (Bakker \& Demerouti, 2008; Chen, Westman, \& Hobfoll, 2015). Using the job-resources or demands model, Cooke, Cooper, Bartram, Wang and Mei (2016) found that employee resilience mediates the relationship between high-performance work systems and employee engagement within the context of Chinese banking.

In a sales context, resilience may act as a moderating variable between employee engagement and a different organisational outcome. Medhurst and Albrecht (2011) found that resilience influences a salesperson's performance through engagement and the investment of high levels of energy when faced with challenging situations. In addition, although resilience did not predict employee engagement for the population under study, this may be different in other populations.

\section{Hypothesis 2: Can it be predicted with reasonable accuracy that a relationship exists between perceived organisational support and employee engagement in a sales environment?}

Perceived organisational support not only predicted approximately $23 \%$ of the variance in employee engagement $(F=27.20, p<0.05)$ but also proved the regression coefficient to be statistically significant $(\beta=0.44, p<0.05)$. This outcome is consistent with the results of earlier studies based on similar theory (Saks, 2006). According to social exchange theory, employees with high POS will engage in greater jobrelated efforts (Kurtessis et al., 2015). In more recent international and South African studies, positive organisational support was positively associated with a high level of engagement (Mathumbu \& Dodd, 2013; Trinchero, Brunetto \& Borgonovi, 2013).

It is also plausible that the relationship between the two constructs can be defined beyond prediction. Shantz, Alfes and Latham (2014) suggest that POS moderates the relationship between work engagement and behavioural outcomes such as turnover intentions and deviant behaviours. In a study of nurses, affective commitment mediated the relationship between POS and work engagement (Gupta, Agarwal, \& Khatri, 2016).

While formulating the hypothesis, it was not assumed that employee engagement as an outcome would be entirely explained by the predictive power of the independent variable. Perceived organisational support predicted nearly a quarter $(23 \%)$ of the outcome, which means that the majority, or almost three quarters of the predictive power of engagement, is still explained by different independent variables. It is also important to take into account that different predictors or drivers of employee engagement are interrelated and do not function separately. Examples of predictors of engagement reported in sales literature include role conflict, role ambiguity, activity and capability control, and adaptive selling behaviour (Miao \& Evans, 2013), trust, psychological contract and interactional justice (Agarwal, 2014). 


\section{Practical implications}

Employee engagement is a continuous process in need of integration across all facets of the employer-employee relationship and employee life cycle (Albrecht et al., 2015). Direct supervisors and sales managers should treat employee engagement as a priority and actively take responsibility for driving the process. Although there are many stakeholders involved in creating a culture of engagement, line managers and direct supervisors ought to be the ultimate owners of engagement (Aon Hewitt, 2015).

Resilience is pliable and open to development (Krush et al., 2013) and resilience should thus be viewed as a set of skills that can be developed as part of strategic human resource management. Resilience-building programmes have proven to be effective in the workplace with a positive effect on health, well-being and performance (Robertson, Cooper, Sarkar, Curran, \& Cooper, 2015; Vanhove et al., 2015). This can be of particular importance in the stressful nature of a competitive sales environment.

With supervisor support being identified as an antecedent of POS (Morelli \& Braganza, 2012), sales managers should maintain a reflective outlook on the quality and level of their supervision and support towards sales staff. A high level of supervisor support has the ability to reduce burnout and ultimately staff turnover (DeConinck et al. 2015). With fairness being one of the precursors of POS (Morelli \& Braganza, 2012), managers responsible for the allocation of sales territories, structuring of sales targets and performance packages play an important role in making decisions that are perceived by sales staff as fair. Human resource practices is the third antecedent of POS (Morelli \& Braganza, 2012). A study by Zampetakis (2014) indicated that human resource management practices such as training, performance appraisal and compensation systems play an important role in creating supportive environments for sales employees. Individually or collectively, the above-mentioned factors may assist in creating an engaged sales force.

\section{Limitations and recommendations}

The limitations of this study are mainly linked to shortcomings related to impact and generalisation. Firstly, the sample in this study was derived from a single pharmaceutical organisation with sales roles predominantly focused on doctor detailing and business-to-business selling. The results may consequently not be generalisable to sales employees working in differentindustries. Secondly, with pharmaceutical sales representatives working in a knowledge-intensive and science-based economy, the results may not be generalisable to sales employees working in other environments (e.g. telesales or retail sales). Thirdly, a cross-sectional research design provided only a snapshot of the specific time frame used. A different time frame containing dynamics such as restructuring or organisational change may have produced different results.
To validate and generalise the results of this study, future research should replicate the predictive relationship between POS and employee engagement in different sales organisations across different industries. Employee engagement has not been studied extensively in the South African pharmaceutical context. More research focusing on this sales environment can provide valuable insight on the constructs in question on an industry level. This research did not focus on sales performance as an outcome of employee engagement. An interesting area of research could be to explore how POS mediates the relationship between employee engagement and sales performance. The competitive nature of the pharmaceutical sales environment is bound to intensify with an increased focus on industry profit margins, and gaining and protecting market share. Demand for pharmaceuticals in South Africa is likely to rise in the future, reflecting demographic and epidemiological trends as well as government commitments to improved healthcare. Yet, the South African pharmaceutical industry will become more constrained (IMS Health, 2014) with squeezed industry margins due to increased drug pricing, intensified regulation of drug prices and the impact of inflation and exchange rate fluctuations on manufacturers. As a result, management will increasingly scrutinise sales performance as a driver of revenue.

Research measuring resilience as a single construct in a different context using the BRS would make a valuable contribution towards demonstrating the reliability and validity of the scale in the South African context as an emerging country. The positive association between employee engagement efforts and staff retention is well documented (Bande et al. 2015). Taking into consideration concerns related to high sales force turnover (Johnson, Friend, \& Rutherford, 2016), future research can explore the moderating effect of POS and employee engagement on intention of sales staff to leave the organisation.

\section{Conclusion}

Employee engagement remains a burning issue across corporate, consulting and academic domains. In the dynamic and competitive topography of sales, employee engagement has immense opportunities to impact business success. Resilience has the potential to reframe the challenging nature of sales positions into a more progressive and desirable occupational domain, while POS can be used by organisations as a social currency to increase employee engagement and ultimately sales performance. The results of this study provided insights that will encourage conversations and future research in a domain that is critical for organisational survival and success.

\section{Acknowledgements}

The article is based on partial fulfilment of the requirements for the degree of Master of Business Administration. 


\section{Competing interests}

The authors declare that they have no financial or personal relationships which may have inappropriately influenced them in writing this article.

\section{Authors' contributions}

The study was undertaken as part of A.M.'s studies at the Gordon Institute of Business Science. K.H. supervised the research project.

\section{References}

Abiola, T., \& Udofia, O. (2011). Psychometric assessment of the Wagnild and Young's resilience scale in Kano, Nigeria. BMC Research Notes, 4(1), 509. https://doi. org/10.1186/1756-0500-4-509

Adamson, B., Dixon, M., \& Toman, N. (2013). Dismantling the sales machine. Harvard Business Review, 99(11), 102-109.

Agarwal, U. (2014). Linking justice, trust and innovative work behaviour to work engagement. Personnel Review, 43(1), 41-73. https://doi.org/10.1108/PR-02 2012-0019

Albrecht, S., Bakker, A., Gruman, J., Macey, W., \& Saks, A. (2015). Employee engagement, human resource management and practices and competitive advantage. Journal of Organizational Effectiveness, 2(1), 7-35. Retrieved from https://doi.org/10.1108/JOEPP-08-2014-0042

Albrecht, S., \& Medhurst, A. (2011). Salesperson engagement and performance : A theoretical model. Journal of Management \& Organization, 17(3), 398-411. https://doi.org/10.1017/S1833367200001541

Amat, S., Subhan, M., Marzuki, W., Jaafar, W., Mahmud, Z., Suhaila, K., \& Johari, K. (2014). Evaluation and psychometric status of the Brief Resilience Scale in a sample of Malaysian international students. Asian Social Science, 10(18), 240245. https://doi.org/10.5539/ass.v10n18p240

Aon Hewitt. (2015). 2015 Trends in Global Employee Engagement. Retrieved from www.aonhewitt.com/2015_TGEE_Download

Bailey, C., Madden, A., Alfes, K., \& Fletcher, L. (2015). The meaning, antecedents and outcomes of employee engagement: A narrative synthesis. International Journal of Management Reviews, 1-23. Retrieved July 20, 2016 from https://onlinelibrary. of Management Reviews, 1-23. Retrieved
wiley.com/doi/full/10.1111/ijmr.12077

Bakker, A., Albrecht, S., \& Leiter, M. (2011). Key questions regarding work engagement. European Journal of Work, 20(1), 4-28. https://doi.org/10.1080/135943 2X.2010.485352

Bakker, A., \& Demerouti, E. (2008). Towards a model of work engagement. Career Development International, 13(209-223). Retrieved from http://www. emeraldinsight.com/doi/full/10.1108/13620430810870476

Bakker, A., \& Demerouti, E. (2014). Job demands-resources theory. Wellbeing, III, 1-28. https://doi.org/10.1002/9781118539415.wbwell019

Bande, B., Fernández-Ferrín, P., Varela, J. A., \& Jaramillo, F. (2015). Industrial marketing management emotions and salesperson propensity to leave: The effects of emotional intelligence and resilience. Industrial Marketing Management, 44, 142-153. https://doi.org/10.1016/j.indmarman.2014.10.011

Baran, B. E., Shanock, L. R., \& Miller, L. R. (2012). Advancing organizational support theory into the twenty-first century world of work. Journal of Business and Psychology, 27(2), 123-147. https://doi.org/10.1007/s10869-011-9236-3

Bardoel, E. A., Pettit, T. M., De Cieri, H., \& McMillan, L. (2014). Employee resilience: An emerging challenge for HRM. Asia Pacific Journal of Human Resources, 52(3), 279-297. https://doi.org/10.1111/1744-7941.12033

Bonanno, G. (2004). Loss, trauma, and human resilience: Have we underestimated the human capacity to thrive after extremely adverse events? American Psychologist, 59(1), 20-28. https://doi.org/10.1037/0003-066X.59.1.20

Bonanno, G. A., Papa, A., \& O'Neill, K. (2001). Loss and human resilience. Applied and Preventive Psychology, 10(3), 193-206. https://doi.org/10.1016/S0962-1849 (01)80014-7

Caesens, G., Marique, G., Hanin, D., \& Stinglhamber, F. (2016). The relationship between perceived organizational support and proactive behaviour directed towards the organization. European Journal of Work and Organizational Psychology, 25(3), 398-411. https://doi.org/10.1080/1359432X.2015.1092960

Chen, S., Westman, M., \& Hobfoll, S. (2015). The commerce and crossover of resources: Resource conservation in the service of resilience. Stress and Health Journal of the International Society for the Investigation of Stress. Retrieved from http://onlinelibrary.wiley.com/doi/10.1002/smi.2574/full

Coetzee, M., Schreuder, D., \& Tladinyane, R. (2014). Employees'work engagement and job commitment: The moderating role of career anchors. South African Journal of Human Resources Management, 12(1), 88-99. https://doi.org/10.4102/sajhrm. v12i1.572

Connelly, C. E., Gallagher, D. G., \& Gilley, K. M. (2007). Organizational and client commitment among contracted employees: A replication and extension with temporary workers. Journal of Vocational Behavior, 70(2), 326-335. https://doi. org/10.1016/j.jvb.2006.10.003
Cooke, F., Cooper, B., Bartram, T., Wang, J., \& Mei, H. (2016). Mapping the relationships between high-performance work systems, employee resilience and engagement: A study of the banking industry in China. The International Journal engagement: A study of the banking industry in China. The International Journal
of Human Resource Management, 1-22. https://doi.org/10.1080/09585192.201 of Human

Coyle-Shapiro, J., \& Morrow, P. (2006). Organizational and client commitment among contracted employees. Journal of Vocational Behaviour, 68, 416-431. https://doi. org/10.1016/j.jvb.2005.10.002

Dageid, W., \& Gronlie, A. (2015). Measuring resilience and its association to social capital among HIV-positive South Africans living in a context of adversity. Journal of Community Psychology, 43(7), 832-848. https://doi.org/10.1002/jcop

DeConinck, J., DeConinck, M. B., \& Lockwood, F. (2015). Influence of job fit, perceived support, and organizational identification in the Sales Force: An analysis of antecedents and outcomes. Archives of Business Research, 3(5). https://doi. org/10.14738/abr.35.1489. Retrieved July 12, 2016 from http://www.sseuk.org/ index.php/ABR/issue/view/74

Edwards, S. D., Edwards, D. J., \& Highley, J. A. (2015). Evaluation of HeartMath training programme for improving personal resilience and psychophysiological coherence. African Journal for Physical Health Education African Journal for Physical Health Education, Recreation and Dance, 21(32), 996-1008.

Eisenberger, R. (1986). Perceived Organizational Support. Journal of Applied Psychology, 71(3), 500-507. https://doi.org/10.1037/0021-9010.71.3.500

Field, A. (2013). Discovering statistics using IBM SPSS statistics. Sage. Retrieved from https://studysites.uk.sagepub.com/field4e/

Freedman, T. G. (2004). Voices of 9/11 first responders: Patterns of collective resilience. Clinical Social Work Journal, 32(4), 377-393. https://doi.org/10.1007/ resilience. Clinical Socic

Gupta, V., Agarwal, U. A., \& Khatri, N. (2016). The relationships between perceived organizational support, affective commitment, psychological contract breach, organizational citizenship behaviour and work engagement. Journal of Advanced Nursing, 72(11), 2806-2817. https://doi.org/10.1111/jan.13043

Gupta, N., \& Sharma, V. (2016). Exploring employee engagement - A way to better business performance. Global Business Review, 17(3S), 1-19. https://doi. org $/ 10.1177 / 0972150916631082$

Harter, J., Schmidt, F., Agrawal, S., \& Plowman, S. (2013). The relationship between engagement at work and organizational outcomes. Gallup Poll. Washington, DC. Retrieved from http://employeeengagement.com/wp-content/uploads/2013/ 04/2012-Q12-Meta-Analysis-Research-Paper.pdf

IMS Health. (2014). Global outlook for medicines through 2018. Retrieved from www. imshealth.com

Johnson, J., Friend, S., \& Rutherford, B. (2016). Absolute versus relative sales failure. Journal of Business Research, 69, 596-603. Retrieved from http://www. sciencedirect.com/science/article/pii/S014829631500226X

Johnson, S., Cooper, C., Cartwright, S., Donald, I., Taylor, P., \& Millet, C. (2005). The experience of work-related stress across occupations. Journal of Managerial Psychology, 20(2), 178-187. https://doi.org/10.1108/02683940510579803

Jowkar, B., Friborg, O., \& Hjemdal, O. (2010). Cross-cultural validation of the Resilience Scale for Adults (RSA) in Iran. Scandinavian Journal of Psychology, 51(5), 418-425. https://doi.org/10.1111/j.1467-9450.2009.00794.x

Kahn, W. A. (1990). Psychological conditions of personal engagement and disengagement at work. Academy of Management Journal, 33(4), 692-724. https://doi.org/10.2307/256287

King, D. D., Newman, A., \& Luthans, F. (2015). Not if, but when we need resilience in the workplace. Journal of Organizational Behavior, 37(5), 782-786. https://doi. org/10.1002/job.2063

Knofczynski, G., \& Mundfrom, D. (2007). Sample sizes when using multiple linear regression for prediction. Educational and Psychological Measurement, 68(3) 431-442. https://doi.org/10.1177/0013164407310131

Koen, M., van Eeden, C., \& Wissing, M. (2011). The prevalence of resilience in a group of professional nurses. Journal of Interdisciplinary Health, 16(1), 1-11. https://doi. org/10.4102/hsag.v16i1.576

Kotzé, M., \& Nel, P. (2013). Psychometric properties of the adult resilience indicator. SA Journal of Industrial Psychology, 39(2), 1-11. https://doi.org/10.4102/sajip. v39i2.1132

Krush, M. T., Agnihotri, R. A. J., Trainor, K. J., \& Krishnakumar, S. (2013). The salesperson's ability to bounce back: Examining the moderating role of resiliency on forms of intrarole job conflict and job attitudes, behaviors and performance. on forms of intrarole job conflict and job attit
Marketing Management Journal, 23(1), 42-56.

Kurtessis, J. N., Eisenberger, R., Ford, M. T., Buffardi, L. C., Stewart, K. A., \& Adis, C. S. (2015). Perceived organizational support a meta-analytic evaluation of organizational support theory. Journal of management, 10(5), 1-31. https://doi. organizational support theory. Journd

Lai, J. C., \& Yue, X. (2014). Using the brief resilience scale to assess Chinese people's ability to bounce back from stress. SAGE Open, 4(4), 2158244014554386. https:// doi.org/10.1177/2158244014554386

Loveland, J., Lounsbury, J., Park, S., \& Jackson, D. (2015). Are salespeople born or made ? Biology, personality, and the career satisfaction of salespeople. Journal of Business \& Industrial Marketing, 30(2), 233-240. https://doi.org/10.1108/JBIM12-2012-0257

Luthans, F. (2002). The need for and meaning of positive organizational behavior Journal of Organizational Behavior, 23, 695-706. https://doi.org/10.1002/job.165

Luthans, F., Vogelgesang, G., \& Lester, P. (2006). Developing the psychological capital of resiliency. Human Resource Development Review, 5(1), 25-44. https://doi. org/10.1177/1534484305285335 
Mache, S., Vitzthum, K., Wanke, E., David, A., Klapp, B., \& Danzer, G. (2014). Exploring the impact of resilience, self-efficacy, optimism and organizational resources on the impact of resilience, self-efficacy, op
work engagement. Work, 47(4), 491-500.

Mäkikangas, A., Feldt, T., Kinnunen, U., \& Mauno, S. (2013). Does personality matter? A review of individual differences in occupational well-being. Advances in Positive Organizational Psychology, 1, 107-143. https://doi.org/10.1108/S2046-410X (2013)0000001008

Maslach, C., \& Leiter, M. (1997). The truth about burnout: How organizations cause personal stress and what to do about it. San Francisco, CA: Wiley.

Mathumbu, D., \& Dodd, N. (2013). Perceived organisational support, work engagement and organisational citizenship behaviour of nurses at Victoria Hospital. Journal of Psychology, 4(2), 87-93. https://doi.org/10.1080/09764224.2 013.11885497

Medhurst, A., \& Albrecht, S. (2011). Salesperson engagement and performance: A theoretical model. Journal of Management and Organization, 77(3), 398-411. https://doi.org/10.1017/S1833367200001541

Medhurst, A., \& Albrecht, S. (2016). Salesperson work engagement and flow: A qualitative exploration of their antecedents and relationship. Qualitative Research in Organizations and Management: An International Journal, 11(1), 22-45. https://doi.org/10.1108/QROM-04-2015-128

Miao, C. F., \& Evans, K. R. (2013). The interactive effects of sales control systems on salesperson performance: A job demands-resources perspective. Journal of the Academy of Marketing Science, 41(1), 73-90. https://doi.org/10.1007/s11747 012-0315-4

Morelli, G., \& Braganza, A. (2012). Goal setting barriers : A pharmaceutical sales force case study. International Journal of Human Resource Management, 23(2), 312case study. International Journal of Human Resource
332. https://doi.org/10.1080/09585192.2011.561226

Pallant, J. (2005). Spss Survival Manual (1st ed.). Sydney: Allen \& Unwin. Retrieved from www.allenandunwin.com/spss.htm

Peres, J. F. P., Foerster, B., Santana, L. G., Fereira, M. D., Nasello, A. G., Savoia, M., \& Lederman, H. (2011). Police officers under attack: Resilience implications of an fMRI study. Journal of Psychiatric Research, 45(6), 727-734. https://doi. org/10.1016/j.jpsychires.2010.11.004

Rajan, C., \& Srinivasan, K. (2015). Sales force effectiveness through technical skills - An empirical observation in Indian pharmaceutical industry. Mediterranean Journal of Social Sciences, 6(6), 641-651. https://doi.org/10.5901/mjss.2015.v6n6s2p641

Rapp, A., Bachrach, D., Panagopoulos, N., \& Ogilvie, J. (2014). Salespeople as knowledge brokers: A review and critique of the challenger sales model. Journa of Personal Selling \& Sales Management, 3134(2015), 1-15. https://doi.org/10.1 080/08853134.2014.908126

Rich, B. L., Levine, J. A., \& Crawford, E. R. (2010). Job engagement: Antecedents and effects on job performance. Academy of Management Journal, 53(3), 617-635. https://doi.org/10.5465/AMJ.2010.51468988

Robertson, I. T., Cooper, C. L., Sarkar, M., Curran, T., \& Cooper, R. (2015). Resilience training in the workplace from 2003 to 2014 : A systematic review, 88(3), 533-562. https://doi.org/10.1111/joop.12120

Rothmann, S., \& Rothmann Jr, S. (2010). Factors associated with employee engagement in South Africa. SA Journal of Industrial Psychology, 36(2), 1-12. https://doi.org/10.4102/sajip.v36i2.925

Saks, A. (2006). Antecedents and consequences of employee engagement. Journal of Managerial Psychology, 21(7), 600-619. https://doi.org/10.1108/02683940610690169

Saks, A., \& Gruman, J. (2014). What do we really know about employee engagement? Human Resource Development Quarterly, 25(2), 155-182. https://doi. org/10.1002/hrdq. 21187

Schaufeli, W. B. (2013). What is engagement? In C. Truss, K. Alfes, R. Delbridge, A. Shantz, \& E. Soane (Eds.), Employee Engagement in Theory and Practice (pp. 1-37). London: Routledge.

Schaufeli, W. B., \& Bakker, A. B. (2004). Job demands, job resources, and their relationship with burnout and engagement: A multi-sample study. Journal of Organizational Behavior, 25(3), 293-315. https://doi.org/10.1002/job.248

Schaufeli, W. B., Bakker, A. B., \& Salanova, M. (2006). The measurement of work engagement with a short questionnaire a cross-national study. Educational and engagement with a short questionnaire a cross-
Psychological Measurement, 66(4), 701-716.

Schaufeli, W. B., Salanova, M., González-Romá, V., \& Bakker, A. B. (2002). The measurement of engagement and burnout: $\mathrm{A}$ two sample confirmatory factor analytic approach. Journal of Happiness Studies, 3(1), 71-92. https://doi. analytic approach. Journal of
org/10.1023/A:1015630930326
Shantz, A., Alfes, K., \& Latham, G. P. (2014). The buffering effect of perceived organizational support on the relationship between work engagement and behavioral outcomes. Human Resource Management, 55, 25-38. https://doi. org/10.1002/hrm.21653

Shin, J., Taylor, M. S., \& Seo, M.-G. (2012). Resources for change: The relationships of organizational inducements and psychological resilience to employees' attitudes
and behaviors toward organizational change. Academy of Management Journal, 55(3), 727-748. https://doi.org/10.5465/amj.2010.0325

Simons, J., \& Buitendach, J. (2013). Psychological capital, work engagement and organisational commitment amongst call centre employees in South Africa. SA Journal of Industrial Psychology, 39(2), 1-12. https://doi.org/10.4102/sajip. v39i2.1071

Smit, W., Stanz, K., \& Bussin, M. (2015). Retention preferences from a multigeneration workforce perspective: The relationship between total rewards, perceived organisational support, and perceived supervisor support. SA Journal of Human Resource Management, 13(1), 1-13. https://doi.org/10.4102/sajhrm. v13i1.665

Smith, B., Dalen, J., Wiggins, K., Tooley, E., Christopher, P., \& Bernard, J. (2008). The brief resilience scale: Assessing the ability to bounce back. International Journal of Behavioral Medicine, 15, 194-200. https://doi.org/10.1080/10705500802222972

Smith, B., Tooley, E., Christopher, P., \& Kay, V. (2010). Resilience as the ability to bounce back from stress: A neglected personal resource? The Journal of Positive Psychology, 5(3), 166-176. https://doi.org/10.1080/17439760.2010.482186

Tavares, S. M., van Knippenberg, D., \& van Dick, R. (2015). Organizational identification and "currencies of exchange": Integrating social identity and social exchange perspectives. Journal of Applied Social Psychology, 46(1), 34-45. https://doi. org/10.1111/jasp.12329

Towers Watson. (2012). Global workforce study: Engagement at risk: Driving strong performance in a volatile global environment. Retrieved from https://www. towerswatson.com

Towers Watson. (2015). The Power of Three. Retrieved from www.towerswatson.com

Trinchero, E., Brunetto, Y., \& Borgonovi, E. (2013). Examining the antecedents of engaged nurses in Italy: Perceived organisational support (POS); satisfaction with training and development; discretionary power. Journal of Nursing Management, 21(6), 805-816. https://doi.org/10.1111/jonm.12143

Vanhove, A. J., Herian, M. N., Perez, A. L. U., Harms, P. D., \& Lester, P. B. (2015) Can resilience be developed at work? A meta-analytic review of resilience-building programme effectiveness. Journal of Occupational and Organizational Psychology, programme effectiveness. Journal of Occupational
89, 1-30. https://doi.org/10.1111/joop.12123

Verbeke, W., Dietz, B., \& Verwaal, E. (2011). Drivers of sales performance: A contemporary meta-analysis. Have salespeople become knowledge brokers?
Journal of the Academy of Marketing Science, 39(3), 407-428. https://doi. Journal of the Academy of Mork
org/10.1007/s11747-010-0211-8

Webster, J. R., \& Adams, G. A. (2010). Organizational support and contract fulfillment as moderators of the relationship between preferred work status and performance. Journal of Business and Psychology, 25(1), 131-138. https://doi. performance. Journal of Business
org/10.1007/s10869-009-9135-z

Werhane, W., \& Royal, M. (2009). Engaging and enabling employees for company success. Magazine of WorkatWork, 1-5. Retrieved from https://www. worldatwork.org

Worley, J. A., Fuqua, D. R., \& Hellman, C. M. (2009). The survey of perceived organisational support: Which measure should we use? SA Journal of Industrial Psychology, 35(1), 112-116. https://doi.org/10.4102/sajip.v35i1.754

Windle, G., Bennett, K. M., \& Noyes, J. (2011). A methodological review of resilience measurement scales. Health and quality of life outcomes, 9(1), 1. https://doi. org/10.1186/1477-7525-9-8

Xanthopoulou, D., Bakker, A. B., Demerouti, E., \& Schaufeli, W. B. (2007). The role of personal resources in the job demands-resources model. International Journal of Stress Management, 14(2), 121-141. https://doi.org/10.1037/1072-5245.14.2.121

Yong, A., \& Pearce, S. (2013). A Beginner's guide to factor analysis: Focusing on exploratory factor analysis. Tutorials in Quantitative Methods, 9(2), 79-94. https://doi.org/10.20982/tqmp.09.2.p079

Zampetakis, L. (2014). Sales force management practices in organizations with a supportive climate towards creativity. Journal of Strategic Marketing, 22(1), 59-72. https://doi.org/10.1080/0965254X.2013.876062

Zikmund, W., Babin, B., Carr, J., \& Griffin, M. (2010). Business Research Methods (8th edn.). OH: South-Western Cengage Learning. 